\title{
Erratum to: Relationship Between Localization of Gold Mining Areas and Hair Mercury Levels in People from Bolivar, North of Colombia
}

\author{
Jesús Olivero-Verbel • Karina Caballero-Gallardo • \\ José Marrugo Negrete
}

Published online: 17 June 2011

(C) Springer Science+Business Media, LLC 2011

\section{Erratum to: Biol Trace Elem Res DOI 10.1007/s12011-011-9046-5}

In the original version of this article unfortunately the last name of the last author appears incorrectly. It should be listed as "Jose Marrugo Negrete".

The online version of the original article can be found at http://dx.doi.org/10.1007/s12011-011-9046-5.

J. Olivero-Verbel $(\bowtie) \cdot K$. Caballero-Gallardo

Environmental and Computational Chemistry Group, Faculty of Pharmaceutical Sciences,

University of Cartagena, Cartagena, Colombia

e-mail: joliverov@unicartagena.edu.co

\section{J. M. Negrete}

Water, Applied and Environmental Chemistry Group, University of Córdoba, Montería, Colombia 